The University of San Francisco

USF Scholarship: a digital repository @ Gleeson Library | Geschke Center

2016

\title{
Binational Same-Sex Couples and Families
}

Daniela Domínguez

Jacqueline E. Coppock

Follow this and additional works at: https://repository.usfca.edu/psyc

Part of the Lesbian, Gay, Bisexual, and Transgender Studies Commons, and the Psychology Commons 


\section{(-)SAGE reference}

\section{The SAGE Encyclopedia of LGBTQ Studies}

\section{Binational Same-Sex Couples and Families}

Contributors: Daniela G. Domínguez \& Jacqueline E. Coppock

Edited by: Abbie E. Goldberg

Book Title: The SAGE Encyclopedia of LGBTQ Studies

Chapter Title: "Binational Same-Sex Couples and Families"

Pub. Date: 2016

Access Date: May 29, 2016

Publishing Company: SAGE Publications, Inc.

City: Thousand Oaks,

Print ISBN: 9781483371306 
Online ISBN: 9781483371283

DOI: http://dx.doi.org/10.4135/9781483371283.n46

Print pages: 116-119

@2016 SAGE Publications, Inc.. All Rights Reserved.

This PDF has been generated from SAGE Knowledge. Please note that the pagination of the online version will vary from the pagination of the print book. 
Historically, the topics of same-sex marriage and immigration reform have been debated as separate political issues. Both issues, however, have impacted the lives of LGBTQ immigrants and their American partners. Presently in the United States, families that include same-sex binational couples are part of the increasingly diverse family landscape. Binational couples are defined here as same-sex partnerships in which one spouse or partner is an American citizen or resident and the other is a foreign national. For years, the ideological underpinnings inherent in immigration laws separated committed couples, forced couples into exile, and resulted in the deportation of partners/spouses of Americans under the Defense of Marriage Act (DOMA). This entry describes the sociocultural context in which binational couples are situated and the challenges they face today. In the following sections, the entry presents the demographics of binational families, the ways in which DOMA directly impacted immigration law and the lives of binational families, the positive ramifications DOMA's repeal has had on binational families, and the challenges and obstacles binational families continue to face even after the U.S. Supreme Court struck down state bans on same-sex marriage.

\section{The Demographics of Binational Couples}

As of 2010 , data from the American Community Survey estimated that $12 \%$ of samesex couples in the United States had at least one noncitizen partner. The Williams Institute found that among noncitizen partners in same-sex binational couples, $45 \%$ are Latina/o and $14 \%$ are Asian/Pacific Islander. The majority of noncitizen partners come from Mexico (25\%), Canada (8\%), and the United Kingdom (6\%). Data from the study proposed that a quarter of male binational couples and $39 \%$ of female binational couples are raising an estimated 17,000 children. Another study published by the Williams Institute in 2013 found that from 2005 through 2011, same-sex couples were as likely as opposite-sex couples to be binational.

\section{DOMA's Impact on Binational Couples}

Designed to define marriage as the legal and valid union between a man and a woman, DOMA ensured that same-sex marriages recognized by individual states would not be entitled to more than 1,000 federal marriage benefits, including immigration benefits. Under DOMA, Americans in same-sex relationships were not allowed to bring their noncitizen partner/spouse to the United States or provide citizenship to their settled immigrant partner living with them in the United States. Instead, Americans were forced to decide between staying in the United States without their partner and starting a new life with their family abroad. To comply with immigration law, many binational couples alternated between living in the United States for a few months and abroad for the rest of the year.

Married couples in which one partner is transgender were required to demonstrate that their unions qualified as valid opposite-sex marriages under state law to gain immigration benefits. Foreign nationals living in the United States with their American citizen partners were forced to choose between the following options: face voluntary deportation; apply for a temporary visa; assume undocumented status for an indefinite period of time or, perhaps, for a lifetime; or move the family to another country where same-sex binational families are fully recognized. In many cases, the noncitizen partner's deportation interfered with previously established household relationships and 
Contact SAGE Publications at http://www.sagepub.com.[Page iv]

seriously disrupted Parent-Child attachments. At times, foreign nationals were deported back to countries that criminalize homosexuality and persecute individuals based on their sexual orientation and gender identity or expression; penalties currently range from small fines to death sentences. American citizens who followed their partners after deportation often faced several challenges including leaving their support network, native language, career, and elderly parents behind. Research conducted by Anusha Kassan and Nadine Nakamura in 2013 found that binational couples often immigrated to Canada when the pursuit of legal status by the foreign national through student or work visas in the United States was no longer a viable option.

\section{Hardship Under DOMA}

Because immigration control is partly responsible for nation making and national security, immigration officers rigorously consider sexuality and its overlapping identities including gender, race, and class at the time of admission. Unique barriers surface for LGBTQ immigrants as they are many times situated at the intersection of homophobia, racism, and anti-immigrant sentiment. Moreover, the U.S. economic crisis together with the declared "War on Terror" turned immigration into a disputed sociopolitical topic. After the September 11, 2001, terrorist attacks on the United States, stricter immigration laws induced ongoing psychological stress for immigrant families living in the interior of the nation as they potentially faced long-term family separation as a result of deportation or voluntary departure.

In 2006, researchers working for Immigration Equality and Human Rights Watch found that binational couples living in the United States suffered from emotional hardship and feelings of immobility, isolation, fear, anxiety, and terror as a result of the "forced confidentiality" that came with threats of facing family separation. In the case of samesex binational couples with children, invisibility was perceived as a defensive coping strategy that protected families from experiencing Parent-Child separation. Binational parents had to navigate the persistent tension between recognition and protection. Further, they were forced to make important determinations about disclosure when interacting with various systems (e.g., religious community, employment, and education), especially when they perceived homophobia within their immigrant communities. Same-sex binational couples were forced to learn how to function in a social system while dealing with heterosexism, overt discrimination, violence, and the psychological symptoms that result from helplessness.

In the case of LGBTQ ethnic and racial minorities, language, cultural barriers, and racism inside mainstream LGBTQ groups may interfere with their integration into the local LGBTQ community. For example, Latina/os in same-sex binational relationships frequently have to navigate multiple cultural values including religious beliefs, a strong sense of masculine pride (i.e., machismo), and family loyalty. They are often forced to decide between living their life openly as members of the LGBTQ community or following the conventional expectations of their family of origin and church communities. During their coming-out process, LGBTQ Latina/os often suffer major losses including family, church, and social support. Mainstream LGBTQ groups can create an atmosphere of confusion and distress when they reject or challenge the cultural beliefs, values, and traditions of LGBTQ ethnic and racial minorities.

\section{DOMA's Demise: A Victory for Binational Couples}

While supporters of same-sex marriage argued that DOMA endorsed and legitimized 
Contact SAGE Publications at http://www.sagepub.com.[Page iv]

the inequality to which same-sex couples are subject, opponents of same-sex marriage contended that DOMA legitimately followed a tradition of male-female unions. They argued that providing marriage rights to same-sex couples would lead to a downfall of the "traditional" institution of marriage and damage the health of children. Supporters of family equality claimed that "tradition" should not be confused with discrimination and underlined the constitutional promise of the equal protection of laws for all Americans as the foundation for the fundamental right to marry a person of one's choosing.

On June 26, 2013, supporters of marriage equality claimed victory when the U.S. Supreme Court struck down Section 3 of DOMA in United States $v$. Windsor and recognized marriages of same-sex couples at the federal level. As a result, President Obama directed United States Citizenship and Immigration Services (USCIS) to review immigration visa petitions filed on behalf of a same-sex spouse in the same manner as those filed on behalf of an opposite-sex spouse. With this victory, a number of ParentChild relationships neglected under DOMA were recognized for purposes of citizenship sponsorship and transmission, and foreign nationals married to U.S. citizens were given the opportunity to obtain immigrant visas for their children.

This was a partial win for same-sex binational families residing in nonrecognition states as they were expected to travel and marry in states that recognized same-sex marriage to qualify for immigration benefits. Another challenge faced by binational couples after the U.S. Supreme Court's Windsor decision was the issue of divorce. For same-sex couples residing in states that did not perform same-sex divorces, divorcing spouses was a complex process as there was contentious debate over which jurisdiction should perform the divorce. Thus, if same-sex binational couples married prior to divorcing their spouses, USCIS may have considered the marriage to be polygamous and invalid for immigration benefits.

After the United States $v$. Windsor decision, some states continued to endorse bans on same-sex marriage despite empirical evidence that illustrated the harmful psychological effects of policies restricting marriage rights for same-sex couples. In 2010, Mark L. Hatzenbuehler, Katie A. McLaughlin, Katherine M. Keyes, and Deborah S. Hasin proposed that lesbian, gay, and bisexual (LGB) people living in states with constitutional bans on gay marriage demonstrated a significant increase in the prevalence of mood disorders, generalized anxiety disorder, alcohol use disorders, and psychiatric comorbidity. In contrast, psychiatric disorders did not increase significantly among LGB respondents living in states without constitutional amendments prohibiting same-sex marriage. With this and similar research in mind, supporters of marriage equality advocated for the equal protection, recognition, and mental health of same-sex couples nationwide.

On June 26, 2015, the Supreme Court's landmark decision in Obergefell v. Hodges required all states to issue marriage licenses to same-sex couples, including same-sex binational couples. This decision invalidated state laws banning same-sex marriage, required all states to recognize same-sex marriages previously performed in other jurisdictions, and provided the equal right to divorce regardless of where the couple married. This decision gave same-sex binational couples living in states that had bans on gay marriage the freedom to marry in the state of their choosing and enjoy spousal benefits including all state tax benefits. It is important to state that civil unions or domestic partnerships are not accepted for immigration purposes at this time. It remains unclear exactly how relevant the Supreme Court's decision will be for same- 
SAGE

Contact SAGE Publications at http://www.sagepub.com.[Page iv]

SAGE Reference

sex binational families raising children in a post-Obergefell world.

\section{Today's Struggles}

When United States Citizenship and Immigration Services (USCIS) reviews immigration visa petitions filed on behalf of a same-sex spouse, the government asks couples to provide evidence that their marriages are valid. Same-sex binational couples sometimes have difficulty proving to the Department of Homeland Security that their marriage is a genuine or "bona fide union" because they often lack the same forms of evidence or proof that opposite-sex couples have available (e.g., family and/or friend testimonies of the marriage). As a result, they may find themselves facing unsupported accusations of marriage fraud. An article published by Benjamin Edwards in 2013 argues that immigration officials should understand the culture-specific differences between same-sex and opposite-sex marriages before determining whether a marriage is valid or fraudulent. Although it may be suspicious when an opposite-sex couple has not openly declared their marriage to friends and families, same-sex couples may choose to keep their relationship private to avoid having traumatic conversations with relatives.

Considering available research identifying the prevalence of psychiatric disorders among LGB populations that lived in states with bans on same-sex marriage, special attention should be given to same-sex binational couples that lived in those states for years. Unfortunately, although LGBTQ immigrants are in need of quality health services, including mental health care, research conducted by Karma R. Chavez in 2011 suggested that when LGBTQ immigrants needed help with health care concerns, they turned to family and friends as they perceived a lack of cultural competence and cultural awareness from service providers.

\section{Conclusion}

Overturning Section 3 of DOMA yielded significant victories for same-sex binational families, such as eligibility to obtain immigration benefits for foreign national partners and the potential for children of foreign nationals in same-sex-binational relationships to gain immigrant visas. Nevertheless, numerous obstacles and threats continue to affect these families even after the Supreme Court's decision to invalidate state bans on same-sex marriage in Obergefell $v$. Hodges.

The U.S. Constitution grants the legislative and the executive branches sole power to regulate all aspects of immigration law. Congress, for example, has the power to exclude immigrants from entering the United States. Thus, even in a post-Obergefell world, same-sex couples remain vulnerable to the power Congress holds to change immigration law. While marriage equality provides undeniable positive outcomes for same-sex binational families, unrelenting hardships uphold the necessity for continued attention to this population.

On November 20, 2014, President Obama announced a series of executive actions to provide up to 5 million undocumented immigrants protection from deportation. Although these measures aim to help immigrants who have U.S. citizen children and spouses, such protection excludes more than 267,000 undocumented LGBTQ immigrants, many of whom are unmarried LGBTQ binational couples. With that in mind, future immigration reform needs to be LGBTQ-inclusive and protect undocumented LGBTQ immigrants from being deported to countries that criminalize homosexuality. Although many same- 
Contact SAGE Publications at http://www.sagepub.com.[Page iv]

sex binational couples have celebrated the repeal of DOMA and the Supreme Court's decision in Obergefell $v$. Hodges, inclusive immigration reform and policy at the state level are needed to fully recognize and protect unmarried same-sex binational families.

See alsoDefense of Marriage Act (DOMA); Discrimination Against LGBTQ People by Law Enforcement; Freedom to Marry (and Other Marriage Equality Organizations); Immigration; Marriage Equality, Landmark Court Decisions

Daniela G. Domínguez Jacqueline E. Coppock

http://dx.doi.org/10.4135/9781483371283.n46

10.4135/9781483371283.n46

Further Readings

Canaday, M. (2009). The straight state: Sexuality and citizenship in twentieth-century America. Princeton, NJ: Princeton University Press.

Chavez, K. R. (2011). Identifying the needs of LGBTQ immigrants and refugees in southern Arizona. Journal of Homosexuality, 58(2), 189-218.

Domínguez, D. G., Solórzano, B. H., \& Peña, E. (2012). Non-heterosexual binational families: Resilient victims of sexual prejudice and discriminatory immigration policies. Journal of GLBT Family Studies, 8(5), 496-508.

Edwards, B. P. (2013). Welcoming a post-DOMA world: Same-sex spousal petitions and other post-Windsor immigration implications. Family Law Quarterly, 47(2), 173189.

Hatzenbuehler, M. L., McLaughlin, K. A., Keyes, K. M., \& Hasin, D. S. (2010). The impact of institutional discrimination on psychiatric disorders in lesbian, gay, and bisexual populations: A prospective study. American Journal of Public Health, 100, 452 $-459$.

Human Rights Watch, \& Immigration Equality. (2006). Family, unvalued: Discrimination, denial, and the fate of binational same-sex couples under U.S. law. New York, NY: Author. Retrieved February 16, 2016, from https://www.hrw.org/sites/default/files/reports/FamilyUnvalued.pdf

Kassan, A., \& Nakamura, N. (2013). "This was my only option": Career transitions of Canadian immigrants in same-sex binational relationships. Journal of LGBT Issues in Counseling, 7(2), 154-171.

Konnoth, C. J., \& Gates, G. J. (2011). Same-sex couples and immigration in the United States. Los Angeles, CA: Williams Institute. 